\title{
GEN 4 : 7 IN THE TARGUIMS AND RABBINIC LITERATURE *
}

The story of Cain and Abel is given a broad spectrum of interpretations in modern exegesis ${ }^{1}$. The most disputed passage in this story is Gen 4:7, which contains Yahweh's statement addressed to Cain:

hălo' 'im-têtî́b 'se'et

$w^{e}$ 'im lo' têțîb lappetah hațta't robesș

$w^{e}$ 'èlèkā $t^{e}$ šûqūtô $w^{e}$ 'attāh timšŏl-bô (quoted according to the TM).

Modern scholars are in agreement that this text does not belong to the earliest version of the story of Cain and Abel, but is rather a Yahwistic embellishment ${ }^{2}$. It is also believed that the Yahwist's text is not free from distorsions which obscure the meaning of the passage ${ }^{3}$. The expression hatțā't robess is particularly difficult to interpret. The difficulty concerns both the grammatical form of this expression and the sense of the word hattā't. From the point of view of grammar there is no agreement between the substantive hatteta't, which is feminine, and the participal adjunct robẹs, which is masculine. As a result the direct sense of the word hatt $\bar{a}^{\prime} t$ is vague. Since the context allows us to leave aside the meaning of ,sin offering" or the name of a female demon or deity ${ }^{4}$, it can indicate either sin as Cain's act which is about to follow (fratricide), or the tendency towards sin inherent in man after the Fall ${ }^{\mathbf{5}}$, or Cain's depressed condition which provides the direct motive for his fratricidal attempt ${ }^{\circ}$.

* Short Communication presented at the XI Congress of the International Organization for the Study of the Old Testament held in Salamanca, Spain, 30 August 1983.

1 The relevant bibliography is to be found in C. W e stermann, Genesis 1-11. Biblischer Kommentar, AT I 1, Neurkirchen 1974, p. 381-384.

2 On the status quaestionis and for recent bibliography see C. W e s t e r m a n n, op. cit., p. 406 and p. 409 410. Among the most recent publications cf. E. D r ewermann, Strukturen des Bösen. Teil 1. Die jahwistische Urgeschichte in exegetischer Sicht, München, 1977, p. 128-131; J. vo n L o e we n cla u, Genesis IV 6-7 - eine jahwistische Erweiterung?, in: Congress Volume Göttingen 1977 (Suppl. to VT XXIX), Leiden, 1978, p. 177-188.

3 On this see C. Westermann, op. cit., p. $409 f$.

* So M. E. Canney, Hațțăth (Gen IV. 7), „Exp. Tim”. 36 (1924-25), p. $525-526$.

5 Cf. G. R. Castellino, Genesis IV 7, VT 10 (1960), p. 442-445.

${ }^{6} \mathrm{Cf}$. M. I. Gruber, The Tragedy of Cain and Abel: A Case of Depression, JQR 79 (1978), p. 89-97. 
In spite of the textual difficulties, the actual state of the biblical text has usually provided the basis for the exposition of the meaning of this verse. The grammatical problem is solved by the following argument: the text employs a metonymy or a personification of sin, or hatt $\bar{a}^{\prime} t$ is masculine here, although it carries a feminine ending. The participle robess is interpreted in the substantive manner, i.e. as referring to a demon ${ }^{7}$. We may quote B. V a w t e r's translation, as an instance of such an interpretation of the text:

"If you do well, you can hold up your head;

but if not, sin is a demon lurking at the door:

his urge is toward you, yet you can be his master" 8 .

Many scholars, however, look for a solution to the problem in a reconstruction of an earlier text. L. R a m a r o s o n's ${ }^{\bullet}$ suggestion seems particularly interesting in this respect. He takes note of the rhythm of the utterance and derives the distorsion of the text from a transposition of the word hatten't from the original to the following line. The original text would then read as follows:
hălo' 'im-têțîb

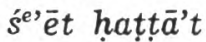
$w^{e '} i m$ lo' têțîb
lappetah robēṣ
$w^{\mathrm{e}}$ 'èlèkā $t^{e}$ šûqūtô
$w^{e}$ 'attāh timšŏl-bô.

The nominal phrase se'ét hațța't means ",remission of sin”, since näśä' hatța't is used in the sense "to remit a sin" both in the Bible and in the Qumran texts. Cain is sad because his offering has not be accepted. Yahweh calls on him to examine his conscience and to confess his $\sin$.

"If you do well, then remission of sin,

but if you do not do well, a demon is standing at your gate:

his designs are against you, but you are to master him".

This reconstruction is further supported by the implications of the Targum interpretation of Gen 4:7. In the rabbinic tradition the word $s^{e}$ 'e $t$ is one of the five words in the Torah without a definitely established reference (cf. Mek Ex 17, 9). According to one exegetic tradition, the one in the Targums, the word $s^{\prime}$ 'êt refers to guilt and sin, while according to another exegetic tradition which modern scholars seem to favour more, the abstract infinitive $s^{e}$ 'et $t$ is an elliptic replacement of $\boldsymbol{s}^{e}$ 'et pānîm - „lifting up of the face”.

There is, however, agreement about the general meaning of the passage in modern exegesis. Yahweh warns Cain of the danger of sin

7 See G. E. Closen, Der „Dämon Sünde” (Ein Deutungsversuch des masoretischen Textes von Gen. 4, 7), "Biblica" 16 (1935), p. 431-442; E. A. S p e is e r, Genesis (AB 1), Garden City, NY, 1964, p. 33.

8 On Genesis, Garden City, NY, 1977, p. 92.

- A propos de Gn 4, 7, „Biblica” 49 (1968), p. 233-237. 
and tells him about good conduct. Many scholars share W. Z i m m e r1 i's ${ }^{10}$ opinion that such a vague text can hardly be used for drawing far-reaching conclusions. It seems therefore that the meaning of this pronouncement about sin should be interpreted in the overall context of the Yahwistic theology of sin, especially with regard to the Yahwist's account of the Fall in the Garden of Eden and Yahweh's words in $6: 3-5$ that man is flesh and his inclinations are always towards evil. As a result, modern readings of Gen $4: 7$ draw on the Yahwist's psychology of sin which is based, firstly, on the recognition of man's free will and moral responsibility, and, secondly, on the theological dimension of $\sin$ as a conscious rejection of God's love while God wants to save man. The Yahwist's theology of sin is based on a profund understanding of human nature, on the psychology of $\sin ^{11}$, and not on a belief in demons or in Satan.

A different interpretation of Gen $4: 7$ is offered by M. Klinger in his book entitled The Mystery of Cain. An Attempt to Place Cain in the Messianic Tradition in Connection with the New Testament Ethical Revolution ${ }^{12}$. He sees Cain's sin in Gen 4:7 in the context of the soteriology of the Orthodox Church. Hence, in his opinion, it is not the psychological but the ontological interpretation of evil in Gen $4: 7$, to be found in Talmud ${ }^{13}$, that is closer to the Yahwist's mentality. Klinger draws the relevant material for his ontological interpretation of evil primarily from the rabbinic Judaism based on various episodes concerning Cain in the Bible, and subsequently also from non-biblical texts. He treats such episodes relatively freely, detecting traces of Cain in the story of Rechabites, in Nathan's prophecy and in the legend of St. George etc. He devotes special attention to the legend of Cain being born of Eve and Satan, which can be found in the Babylonian Talmud.

He starts with the premise that in the ancient Judaic and Christian literatures Cain functions as an archetype of man's union with evil. Compared to Gen 3, the story of Cain is said to contain a new element:

10 1. Mose 1-11. Die Urgeschichte, Zürich \$, 1967, p. 214.

11 A joint publication entitled Brudermord. Zum Mythos von Kain und Abel, hrsg. J. Illies, München, 1975, constitutes an illustration of a psychological interpretation of Cain's sin in modern exegesis and in modern Western theology.

12 Tajemnica Kaina. Próba umiejscowienia Kaina $w$ tradycji mesjańskiej $w$ zwiazku $z$ nowotestamentowa rewolucja, etyczna, Warszawa, 1981.

18 The author quotes the following texts from rabbinic writings which are ment to iudicate the ontological character of $\sin$ in Gen $4: 7: B$. Nid. 30b; B. Yom. 19a; Ber. Rab. 22.

It seems hardly necessary to analyse each of these texts in detail, but if they really treat $\sin$ in Gen 4:7 ontologically, they can be said to belong to the tradition of marginal exegesis, in contrast to most rabbinic texts which treat Cain's. sin in moral terms. 
„There man was dispersed", Klinger writes, ,and though deceived by the snake, he chose separation (from God) of his own will; here he fights against overwhelming odds and, in the ontological aspect, commits himself to $\sin$ both in his life and death. It is not clear who will be the winner; it is difficult even to tell Cain from the dragon of sin. It is known, however, that the Messiah will triumph over the dragon." ${ }^{14}$ Cain, the personification of evil, bears a stigma of guilt, but having also the Messianic promise, he also bears on his forehead a mark symbolizing that hope.

Klinger's interpretation of Gen 4:7 in the Messianic context yields quite interesting insights. Within the framework of Orthodox theology Cain's sin acquires the function of bringing into full relief the soteriological significance of Jesus' baptism in the Jordan and his death on the cross. Ample evidence of this can be found in early Orthodox hymnology, in liturgical texts and iconography. However, the author's thesis that the ontological interpretation of evil in Gen 4:7 is closer to the Yahwist's mentality than is the psychological interpretation of Western exegesis remains debatable, especially as ontological interpretation of Gen 4:7 is typical of rabbinic theology.

A closer study of the various interpretations of Gen 4:7 in the Targums and other rabbinic texts does not permit such conclusions. Even a glance at the Targums and rabbinic writings which contain the quoted text of Gen 4:7 proves that the text emphasizes man's free will rather than determining the doings of Adam's progeny as invariably evil. Thus, the fact that Gen $4: 7$ can be quoted in the Messianic context does not necessarily mean that it is understood as treating ,the ruler of this world" in ontological terms.

Since the Hebrew text is vague, all the versions of the Targums to the Pentateuch give a paraphrase and an explanation of the biblical text rather than its translation. The detailed analysis of the texts of the Targums to Gen $4: 7$ provided by $\mathrm{P}$. Grelot ${ }^{15}$, and subsequently by G. Vermes ${ }^{18}$ and G. J. $\mathrm{Kuiper}{ }^{17}$, shows that the Palestinian Targums offer one form of the interpretation of Gen 4:7. The Onqelos Targum is dependent here on the Palestinian Targums. Also the Pseudo-Jonathan Targum remains in agreement with the Palestinian Targums. As the Neofiti I represents a form of the Palestinian Targum, the text

14 Op. cit., p. 27.

15 Les Targums du Pentateuque. Etude comparative d'après Gen IV, 3-16, „Semitica" 9 (1959), p. 59-88 (on Gen 4:7 p. 68-70).

${ }_{10}$ The Targumic Versions of Genesis IV 3-16, "The Annual of Leeds University Oriental Society" 3 (1961-62), Leiden, 1963, p. "81-114 (on Gen 4:7 p. 100f. 108f.).

17 Targum Pseudo-Jonathan: A study of Genesis 4,7-10,16, „Augustinianum" 10(1970), p. 533-570 (on Gen $4: 7$ p. 535 f. 548-551). 
of the former may provide a basis for the analysis of the notion of $\sin$ in the Targums to Gen 4:7. Here is the relevant excerpt from the English translation to be found in A. Díe $\mathrm{m}$ a cho's edition of this Targum:

"Certainly, if you make good work in this world it (viz. sin) will be remitted and pardoned you in the world to come.

but if you not make good your work in this world until the day of the great judgement your $\sin$ is kept, and at the door of your heart your sin crouches,

but into your hand I have given the dominion of the evil inclination (yişrāh bišă') and you have power over it for justification of for sin" (litt. "to be just or to sin") ${ }^{18}$ :

The Targums treat the words of Yahweh in Gen 4:7 as a teaching about man's responsibility for sin. Targumists interpret the first clause (v. 7a) as a teaching about the remission of sin. Already the LXX understands $\sin$ in Gen 4:7 as a reference to some defect in Cain's offering. The Onqelos Targum assumes Cain's guilt. Other versions do not concentrate on the problem of Cain's guilt or innocence but, as follows from the dialogue between Cain and Abel in the next verse (v. 8), it is the problem of faith in God's justice in His government of the world that is the chief concern here ${ }^{19}$. God's acceptance or rejection of the offering depends entirely on Cain. He does not have to worry about his offering being rewarded or not. If his acts are good, he will be recognized as sinless in the world to come.

The Palestinian Targums contain the following formula which indicates the remission of sin: ,it will be remitted and pardoned you in world to come;" the Pseudo-Jonathan Targum says: „your sin will be forgiven jou", and the Onqelos Targum: ,it will be forgiven you." ${ }^{20}$

The second clause of verse 7 , containing a comparison of sin to a demon, is interpreted by the Targums as the retension of evil deeds until the Day of the Last Judgement. Moreover, the interiorization of Cain's $\sin$ is involved here. The Bible treats Cain's sin as remaining outside him, whereas in the Targums the sin lies at his heart's door. Targumists treat sin here as subject to remission at the Last Judgement either through God's mercy or through the punishement by fire in the Gehenna.

18 Neophyti I. Targum Palestinense. MS de la Biblioteca Vaticana. T. I. Genesis, Madrid, 1968, p. 506.

19 Cf. G. Vermes, The Targumic Versions... p. 100; R. Le Déaut, Traditions targumiques dans le Corpus Paulinien?, „Biblica” 42 (1961), p. $28-40$ (p.301f. for Cain and Abel).

20 For this expression see G. Vermes, The Targumic Versions..., p. 108, and Haggadah in the Onkelos Targum, JSSt 8 (1963), p. 164.

25 - Analecta Cracoviensia 
To emphasize man's domination over evil Targumists interpret the third clause of verse 7, constituing a reproduction of the words of Gen $3: 16$, as stressing man's freedom, even more than the Bible does. Good or baid conduct depends entirely on man himiself, as he is able to control his evil inclination.

The Pseudo-Jonathan Targum adds to the Midrash type interpretation, in the third clause, a literal translation of the biblical expression: ,and its desire shall be towards you." On the other hand the Onqelos Targum departs completely from the Hebrew text in the third clause and introduces its own exegesis which puts special emphasis on repentance: "So it will be punishment for you if you do not repent, but if you repent you will be forgiven." ${ }^{21}$

The Palestinian Tangums to Gen 4:7, Midrash Genesis Rabbah (XXII. 6), Abbot of Rabbi Nathan (16b) and many places in the Talmud (e.g. B.San.91b) interpret Cain's sin in the context of the teaching about the two inclinations in man, a propensity to good and to evil ${ }^{22}$. In the rabbinic theology the evil inclination (yeșer hāra $\bar{a}^{c}$ ) is a part of human nature in thi's world. Every man is born with the evil inclination. There is no universal agreement between the rabbis as to the origins of the evil inclination, but most rabbinic texts maintain that man was created by God with the evil inclination. To balance the evil inclination; God gives to Israel the Torah, which is meant as a medicine for the evil inclination. The acceptance of the Torah gives rise to the good inclination in man. The teaching about the evil inclination emphasizes God's control over all creation and at the same time man's freedom to do good and to be rewarded for his good deeds ${ }^{23}$.

However, there are some texts which blame Satan in Paradise for all the evil in man. It is in this sense that one should understand the rabbinic texts which say that Cain was born of Eve and Satan. According to V. A p tovitze ${ }^{24}$ this legend originated with the Gnostics. In the writings of Christian authors it is said that both Cain and Abel were born of Eve and Satan. In rabbinic writings the legend was altered to emphasize the role of Cain as a type of evil man. Interestingly enough, the Pseudo-Jonathan Targum which quotes the legend of Cain's birth

${ }^{21}$ Some rabbinic texts on Cain's repentance are given in J. B ow ker, The Targums and Rabbinic Literature, Cambridge, 1969, p. $139 \mathrm{f}$.

${ }_{22}$ Relevant texts from rabbinic literature have been collected by $\mathrm{Str}$ a ck-B ill e r b e c k, IV, p. $466-483$.

${ }^{23}$ An exhaustive explanation of the origins of the rabbinic teaching about the evil inclination in man is given by A. L. Thompson in his monograph entitled Responsibility for Evil in the Theodicy of IV Ezra, Missoula, Mont., 1977, p. 4966.

24 Kain und Abel in der Agada den Apokryphen, der hellenistischen, christlichen und muhammedanischen Literatur, Wien, 1922, p. 20 and p. 129 note 92. 
of Eve and Sammael in the interpretation of Gen $4: 1$, does not refer to it the interpretation of Gen $4: 7$. Thus, it may be concluded that the Targum treats $\sin$ in $4: 7$ in the moral rather than the ontological perspective.

To sum up the'se observations it should be emphasized that the rabbinic interpretation of Gen $4: 7$ justifies the reconstruction of the text suggested by $L$. $R$ a m a r o s o $n$. As far as the notion of $\sin$ in Gen $4: 7$ is concerned, the Targumic tradition follow's the lines of the Yahwistic theology in the interpretation of contemporary exegesis. Rabbinic exegesis explains the biblical content in a new linguistic form and in a new theological context. By reference to the teaching about the evil inclination in man, it stresses the anthropological aspect of sin; its theological aspect is emphasized in the context of the teaching about God's love and justice. 